\title{
Agronomic performance of seedless table grape genotypes under tropical semiarid conditions
}

\author{
Patrícia Coelho de Souza Leão1,* (D), José Henrique Bernardino Nascimento² (D), \\ Dayane Silva de Moraes $^{2}$ (D), Edimara Ribeiro de Souza² (D) \\ 1. Empresa Brasileira de Pesquisa Agropecuária - Centro de Pesquisa Agropecuária do Trópico Semi-Árido - Petrolina \\ (PE), Brazil \\ 2. Universidade de Pernambuco - Petrolina (PE), Brazil.
}

\begin{abstract}
The São Francisco Valley is the main producing region of table grape in Brazil. The objective of this work was to evaluate the agronomic performance and physicochemical characteristics of 14 seedless table grape genotypes to select those with potential to be used in commercial crops in the São Francisco Valley, Brazil, or as parents in breeding programs. Theexperimentwas carried out over fivecropseasons(2014to2018), in Petrolina, PE, Brazil. The treatments consisted of 14 seedless table grape genotypes. The results showed significant effects for all variables evaluated. The highest estimated yield per production cycle were found for

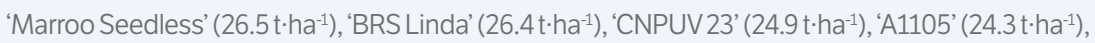
and 'A Dona' (20.2 $\mathrm{t} \cdot \mathrm{ha}^{-1}$ ). Soluble solid (SS) content varied from 13.35 'Brix ('CNPUV 23') to 21.63 Brix ('A Dona'). The titratable acidity (TA) of the genotypes varied from $0.27 \mathrm{~g} \cdot 100 \mathrm{~mL}^{-1}$ ('CNPUV 23') to $0.72 \mathrm{~g} \cdot 100 \mathrm{~mL}^{-1}$ ('Crimson Seedless'). Principal component analysis showed that the first three principal components explained $81.9 \%$ of the data variance, and grouped the best genotypes for production components and fruit chemical composition on different sides of the $X$-axis. These results allowed the identification of a group of seedless grape cultivars that can be used for commercial crops or as parents for controlled crossings in a local table grape breeding program.
\end{abstract}

Key words: Vitis sp., new table grape cultivars, tropical viticulture, table grape breeding.

\author{
Received: \\ Jan. 21, 2020 \\ Accepted: \\ Apr. 14, 2020 \\ Section Editor: \\ Cláudia Sales Marinho \\ ${ }^{\star}$ Corresponding author: \\ patricia.leao@embrapa.br
}

\section{INTRODUCTION}

Viticulture is one of the most important production chains for the irrigated agriculture in the Northeast region of Brazil. The São Francisco Valley is responsible for $63 \%$ of the national production and encompasses $18 \%$ of the Brazilian table grape crop area (IBGE 2017). This production is concentrated in the state of Pernambuco, whose table grape crop area in 2018 was estimated in $6,814 \mathrm{ha}$, with a production of $237.367 \mathrm{t}$, which is the second higher production in the country, after the state of Rio Grande of Sul (Agrianual 2019). Grape is one of the main exported agricultural products in Brazil, and the São Francisco Valley is responsible for $99 \%$ of the grape exported since 2002, with volumes that reached 39,000 $\mathrm{t}$ in 2018 (Agrianual 2019).

In the last decade, great changes were observed in the table grape production chain in Brazil, which were characterized by diversification of cultivars and an increased offer of seedless table grapes in the domestic market. These changes followed the increases of public and private table grape breeding programs worldwide, which resulted in the releasing of several cultivars each year on the global market (Burger et al. 2014; Ataka and Kahraman 2014; Clark and Moore 2015; Xu et al. 2015). Recent studies about the preference of the table grape production sector in China showed that high yield, resistance 
to diseases, good postharvest conservation, high sugar contents, big oval berries with intense red to black color, such as muscatel, are important attributes for the adoption of new table grape cultivars, and the absence of seeds was mentioned as a characteristic of low importance in that country (Wang et al. 2017), although this is currently the most important objective of the genetic breeding table grape projects worldwide (Töpfer et al. 2011).

More than 20 table grape cultivars are currently grown in the São Francisco Valley, mainly seedless table grapes developed by the Brazilian Agricultural Research Corporation (Embrapa), such as 'BRS Vitoria' (Maia et al. 2012) and 'BRS Isis' (Ritschel et al. 2013), and by private international breeding companies.

Despite the increase and economic importance of foreign cultivars introduced to the region, the susceptibility to diseases and lack of adaption to environmental conditions of some of these genetic materials, high cost (royalties) for their production, and limitation of areas required by international companies for their growth have increased the demand for new public table grape cultivars developed in Brazil and adapted to the environmental conditions of the Brazilian Semiarid region.

Seedless table grape cultivars from the Active Germplasm Bank of the Embrapa Semiarid were selected by their production potential and high fertilities of buds (Leão et al. 2017), such as 'A Dona', developed by the Agronomic Institute of Campinas; 'BRS Linda' (Camargo et al. 2003a), 'BRS Clara' (Camargo et al. 2003b), and other advanced cultivars improved by the Embrapa Grape and Wine; and the 'Marroo Seedless', developed by the CSIRO in Australia; 'Romana' or 'A 1105', selected by the University of Arkansas, USA; and 'Arizul' ('CG 351'), developed by the INTA in Argentina. Preliminary works showed the desirable characteristics of 'Marroo Seedless' in the São Francisco Valley (Leão 2002).

The objective of this work was to evaluate the agronomic performance and physicochemical characteristics of fruits of 14 seedless table grape genotypes aiming to select those with potential to be used in commercial crops in the São Francisco Valley, Brazil, or as parents in a local table grape breeding program.

\section{MATERIAL AND METHODS}

The experiment was carried out at the Bebedouro Experimental Field of the Embrapa Semiarid, in Petrolina, PE, Brazil $\left(09^{\circ} 09^{\prime} \mathrm{S} 40^{\circ} 22^{\prime} \mathrm{W}\right.$, and altitude of $365.5 \mathrm{~m}$ ) over five crop seasons (2014 to 2018). The climate of the region is BSwh, very hot semiarid, according to the Köppen classification (Alvares et al. 2014), with average annual air temperature of approximately $26^{\circ} \mathrm{C}$, relative air humidity of $64 \%$, rainfall depth of $549 \mathrm{~mm}$, global solar radiation of $18 \mathrm{MJ} \mathrm{m}^{-2} \cdot$ day ${ }^{-1}$, wind speed of $2 \mathrm{~m} \cdot \mathrm{s}^{-1}$, and reference evapotranspiration of $6 \mathrm{~mm} \cdot \mathrm{day}^{-1}$. Monthly data for air temperature (minimum, average, and maximum), solar global radiation, and rainfall depth from 2014 to 2018 were obtained from an automatic agrometeorological station (Table 1). The soil of the area was classified as a typic plinthudult (red argissol eutrophic abrupt plinthosolic) with moderate A horizon, medium texture, and plain relief (Cunha et al. 2008).

The vineyard used for the experiment was planted in December 2012; it was composed of 14 seedless table grape genotypes grafted on IAC 766 rootstock. The vineyard was trained in a trellis system with spacing between plants of $3.00 \times 2.00 \mathrm{~m}$ (density of 2,666 plants $\cdot \mathrm{ha}^{-1}$ ). A drip irrigation system was used, which consisted of two drippers per vine (each $0.50 \mathrm{~m}$ ) and average flow of $2.10 \mathrm{~L} \cdot \mathrm{h}^{-1}$; the water depth used was calculated daily by the reference evapotranspiration determined by the Class-A tank method (Allen et al. 1998).

The grapevines were pruned at the unilateral cord, using two production pruning per year. Vines were head-training, cane pruning with one replacement spur for each cane and canes wrapped horizontally along a trellis wire. The cultural practices consisted of removal of sprouts, tying of branches and sprouts, thinning of bunches and branches, weed control through herbicide application and manual weeding between rows, and weekly disease control.

The treatments consisted of 14 seedless table grape genotypes: two commercial cultivars used as control, namely Thompson Seedless and Crimson Seedless; six cultivars of different origins, namely Marroo Seedless (CSIRO, Australia), A Dona (IAC, Brazil), Arizul or CG 351 (INTA, Argentina), Romana or A 1105 (University of Arkansas, EUA), and BRS Linda and BRS Clara (EMBRAPA, Brazil); and six genotypes selected in the breeding program of the Embrapa Grape and Wine, namely CNPUV 8, CNPUV 23, CNPUV 24, CNPUV 25, CNPUV 36, and CNPUV 44. 
Table 1. Monthly means and standard deviations for climatic elements: average $\left(T_{\text {Average }}\right)$, maximum $\left(T_{\text {Max }}\right)$, and minimum ( $\left.T_{\text {Min }}\right)$ air temperature; global solar radiation (GSR); and rainfall depth (RD) from 2014 to 2018 in the Bebedouro Experimental Field, Petrolina, PE, Brazil.

\begin{tabular}{ccccccc}
\hline & JAN & FEB & MAR & APR & MAY & JUN \\
\hline $\mathrm{T}_{\text {Average }}\left({ }^{\circ} \mathrm{C}\right)$ & $27.1 \pm 2.0$ & $26.7 \pm 1.5$ & $27.0 \pm 1.2$ & $26.3 \pm 1.5$ & $25.0 \pm 2.0$ & $24.2 \pm 1.0$ \\
\hline $\mathrm{T}_{\text {Max }}\left({ }^{\circ} \mathrm{C}\right)$ & $33.4 \pm 2.5$ & $32.8 \pm 1.9$ & $33.7 \pm 1.6$ & $32.4 \pm 1.9$ & $31.0 \pm 2.4$ & $30.4 \pm 1.6$ \\
\hline $\mathrm{T}_{\text {Min }}\left({ }^{\circ} \mathrm{C}\right)$ & $21.7 \pm 1.6$ & $21.7 \pm 1.5$ & $22.4 \pm 0.8$ & $21.4 \pm 1.0$ & $20.0 \pm 1.6$ & $18.7 \pm 0.6$ \\
\hline $\left.\mathrm{GSR}(\mathrm{MJ} \mathrm{m})^{-2}\right)$ & $18.5 \pm 3.2$ & $18.1 \pm 2.1$ & $18.3 \pm 2.8$ & $16.7 \pm 2.2$ & $15.2 \pm 2.5$ & $14.5 \pm 2.7$ \\
\hline $\mathrm{RD}(\mathrm{mm})$ & $61.7 \pm 90.7$ & $42.8 \pm 15.3$ & $35.2 \pm 39.6$ & $49.0 \pm 42.4$ & $17.8 \pm 14.2$ & $3.0 \pm 3.0$ \\
\hline $\mathrm{T}_{\text {Average }}\left({ }^{\circ} \mathrm{C}\right)$ & $23.7 \pm 1.1$ & $24.9 \pm 1.0$ & $26.4 \pm 1.3$ & $28.0 \pm 0.5$ & $28.9 \pm 1.0$ & 28 \\
\hline $\mathrm{T}_{\text {Max }}\left({ }^{\circ} \mathrm{C}\right)$ & $29.8 \pm 1.8$ & $31.5 \pm 1.5$ & $33.2 \pm 1.5$ & $34.9 \pm 1.0$ & $35.6 \pm 1.2$ & $34.0 \pm 1.5$ \\
\hline $\mathrm{T}_{\text {Min }}\left({ }^{\circ} \mathrm{C}\right)$ & $18.1 \pm 0.6$ & $18.8 \pm 0.5$ & $20.2 \pm 1.0$ & $22.0 \pm 0.4$ & $23.1 \pm 0.7$ & $22.7 \pm 1.1$ \\
\hline $\mathrm{GSR}\left(\mathrm{MJ} \mathrm{m} \mathrm{m}^{-2}\right)$ & $15.1 \pm 2.6$ & $18.7 \pm 3.3$ & $19.9 \pm 3.2$ & $20.7 \pm 3.9$ & $20.7 \pm 3.5$ & $19.8 \pm 3.6$ \\
\hline $\mathrm{RD}(\mathrm{mm})$ & $5.2 \pm 4.2$ & $1.2 \pm 1.5$ & $3.0 \pm 4.6$ & $9.0 \pm 12.4$ & $13.6 \pm 19.5$ & $26.3 \pm 15.7$ \\
\hline
\end{tabular}

A randomized block experimental design with four replications was used. The plots consisted of nine plants each, using two plants for harvesting and fruit evaluation. The fruits were harvested at full maturation stage.

After harvesting, the bunches were counted and weighed in a digital balance. The mean results obtained $\left(\mathrm{kg}^{\circ} \cdot \mathrm{vine} \mathrm{e}^{-1}\right)$ were used to estimate the yield $\left(t \cdot h a^{-1}\right)$, considering the mean production per plant and the number of vines per hectare. The mean bunch weight (g) was obtained considering the total bunch weight and the number of bunches per plant. A five-bunch sample was taken from each plot and evaluated for bunch length and width $(\mathrm{cm})$, using a ruler. The berries were physically and chemically analyzed using 10-berry samples from each bunch, totaling 50 berries per plot, thus determining the berry weight $(\mathrm{g})$, berry length $(\mathrm{mm})$, and berry mean diameter $(\mathrm{mm})$. Total soluble solids $(\mathrm{SS})$ and titratable acidity (TA) contents were evaluated using the juice extracted from 50 berries per plot; SS was evaluated using a digital refractometer, and expressed as ${ }^{\circ} \mathrm{Brix}$; and TA was evaluated using titration with $\mathrm{NaOH} 0.1 \mathrm{~N}$ (AOAC 2010), and expressed as percentage of tartaric acid.

The means of the five production cycles were used for all variables studied, which were subjected to the Shapiro-Wilk normality test. When the data showed normal distribution, they were subjected to analysis of variance ( $\mathrm{F}$ test at $\mathrm{p}<0.05)$, and the means of the treatments were grouped by the Scott-Knott test $(\mathrm{p}<0.05)$. The means were subjected to multivariate analysis of principal components and projected in bi-dimensional space in relation to the principal components 1 and 2 and principal components 1 and 3 (Fig. 1).

\section{RESULTS AND DISCUSSION}

The analysis of variance showed significant effect of the seedless table grape genotypes for all variables evaluated (Table 2); however, bunch length and weight and berry length and diameter did not meet the assumption of normal distribution of residues and were presented as means and standard deviation (Table 3).

The Scott-Knott test formed three groups for estimated yield, showing higher yields for the genotypes Marroo Seedless (26.49 $\left.\mathrm{t} \cdot \mathrm{ha}^{-1}\right)$, BRS Linda $\left(26.44 \mathrm{t} \cdot \mathrm{ha}^{-1}\right)$, CNPUV $23\left(24.96 \mathrm{t} \cdot \mathrm{ha}^{-1}\right)$, A1105 (24.32 $\left.\mathrm{t} \cdot \mathrm{ha}^{-1}\right)$, and A Dona $\left(20.23 \mathrm{t} \cdot \mathrm{ha}^{-1}\right)$; an intermediate group was formed by the genotypes BRS Clara, Arizul, CNPUV 8, CNPUV 36, and CNPUV 44 (Table 2).

The cultivars Thompson Seedless and Crimson Seedless presented lower yield than most genotypes evaluated. The mean yield of grapevines in Brazil is $20.4 \mathrm{t}^{\mathrm{h}} \mathrm{ha}^{-1} \cdot \mathrm{year}^{-1}$; however, the adoption of modern production technologies and irrigation systems increased this yield in the Northeast region to $32 \mathrm{t} \cdot \mathrm{ha}^{-1} \cdot$ year $^{-1}$ (IBGE 2017), i.e., $16 \mathrm{t} \cdot \mathrm{ha}^{-1}$ per production cycle, on average. The estimated yields for the most productive genotype group varied from 20 to $26 \mathrm{t} \cdot \mathrm{ha} \mathrm{a}^{-1}$ per cycle, which were higher than the mean yield in the São Francisco Valley, and similar to those described for the commercial cultivars BRS Vitória (Maia et al. 2013) and BRS Îsis (Ritschel et al. 2013). 
(a)

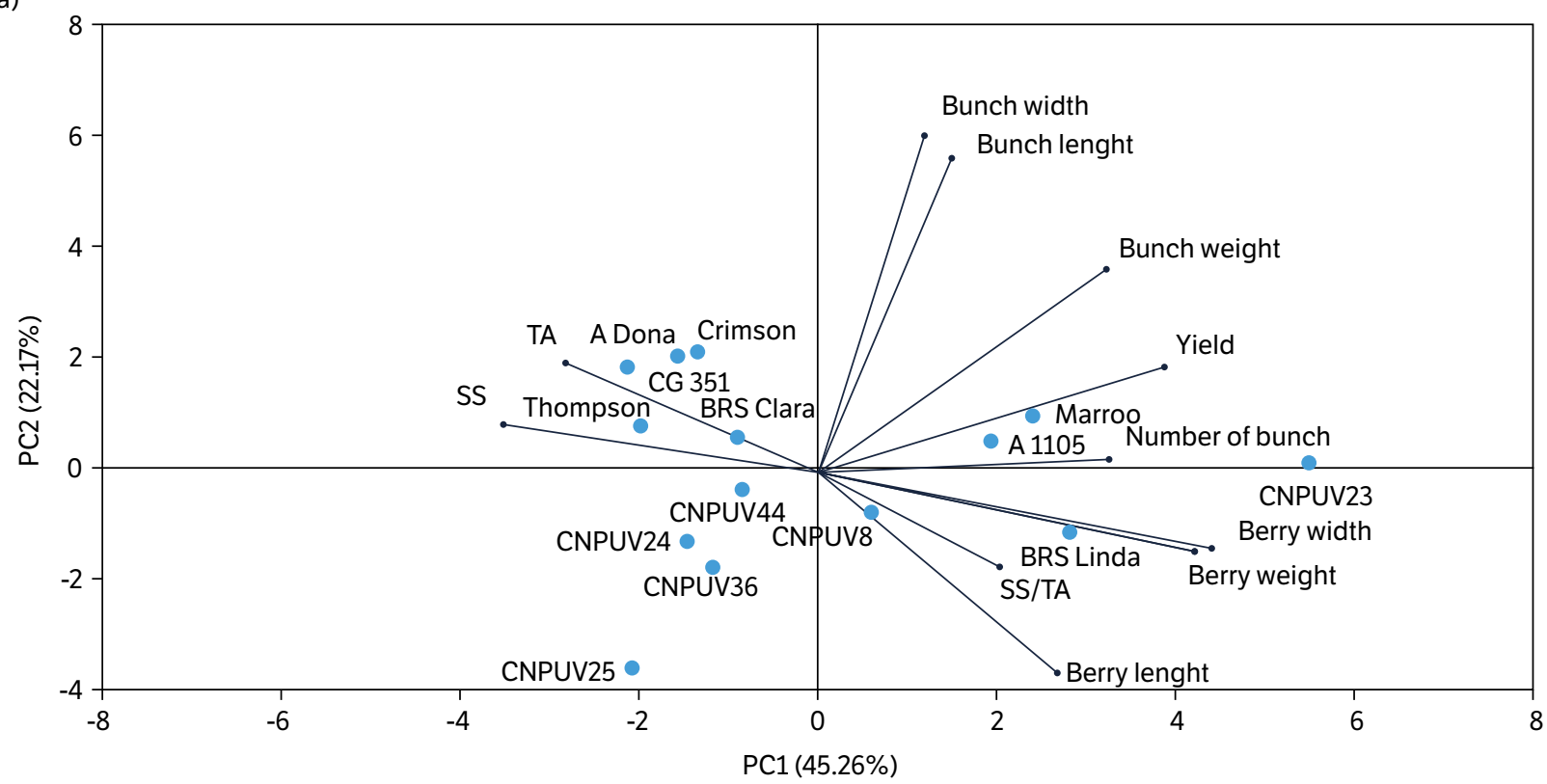

(b)

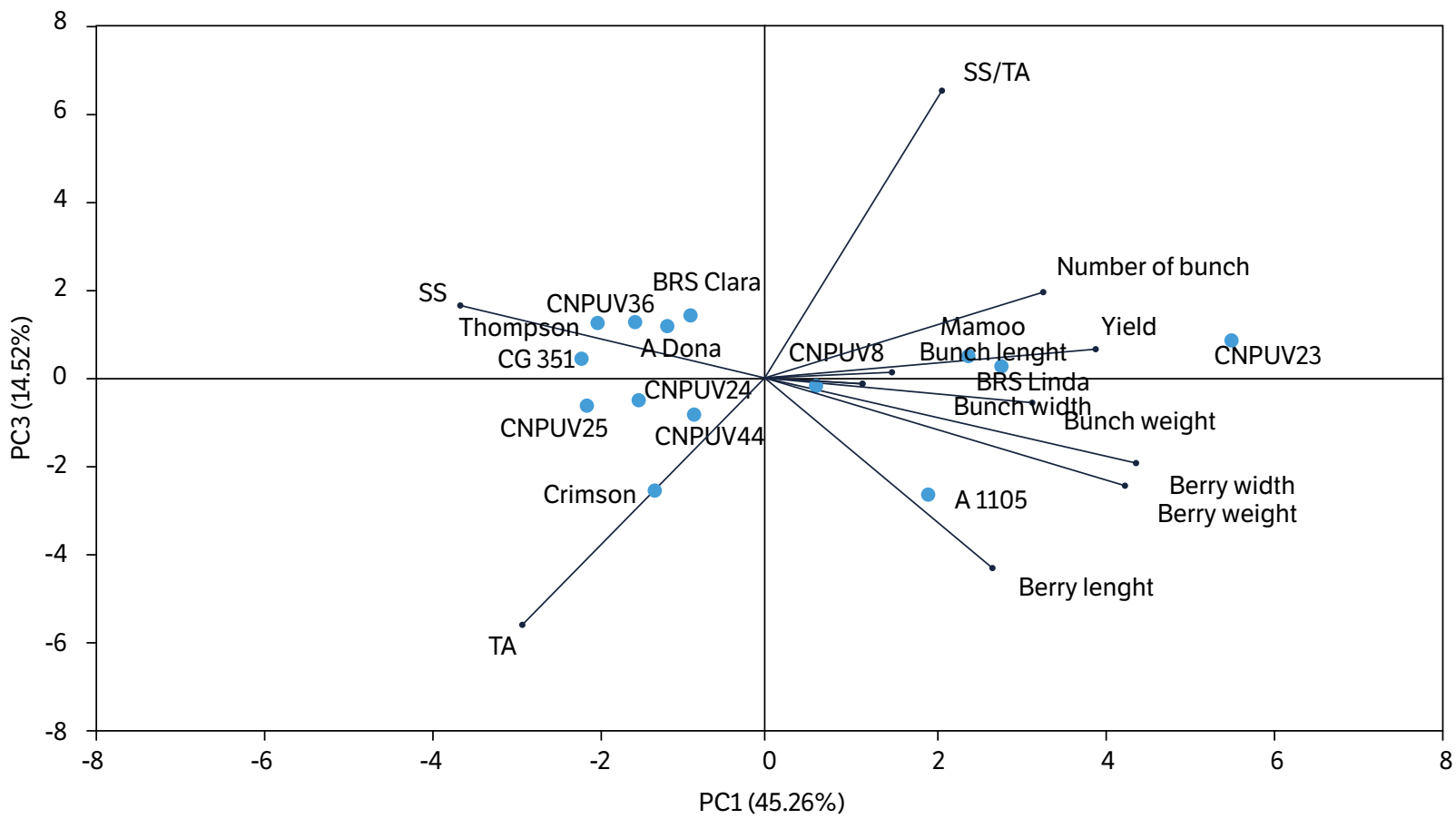

Figure 1. Principal component analysis (PCA) biplot showing the distribution of 14 seedless table grape genotypes over five crop seasons (2014-2018) based on principal components 1 and 2 (a) and principal components 1 and 3 (b).

The number of bunches was high for most genotypes, with mean of 58 bunches per plant, confirming the high fertility of buds, which was a characteristic of the genotypes evaluated in this work (Leão et al. 2017). The genotypes CNPUV 23, Marroo Seedless, and A Dona presented the highest number of bunches. The commercial cultivars Thompson Seedless and Crimson Seedless presented the lowest number of bunches; these cultivars are characterized by low fertility of buds (Leão et al. 2017), which is one of the factors that caused the substitution of these cultivars in the study region.

Bunch and berry weight and size were, in general, lower than those reported for standard commercial crops in the São Francisco Valley, because they were not subjected to the bunch managements that are adopted in the region, especially the 
Table 2. Means and coefficient of variation for yield, number of bunches per plant, bunch weight, bunch width, soluble solid contents (SS), and titratable acidity (TA) of 14 table grape genotypes over five crop seasons (2014-2018). Petrolina, PE, Brazil.

\begin{tabular}{|c|c|c|c|c|c|c|c|}
\hline Genotypes & $\begin{array}{c}\text { Yield } \\
\left(t \cdot h a^{-1}\right)\end{array}$ & $\begin{array}{c}\text { Number } \\
\text { of bunches } \\
\text { per vine }\end{array}$ & $\begin{array}{c}\text { Bunch } \\
\text { weight }(g)\end{array}$ & $\begin{array}{c}\text { Bunch } \\
\text { width }(\mathrm{cm})\end{array}$ & $\begin{array}{c}\text { SS } \\
\left({ }^{\circ} \text { Brix }\right)\end{array}$ & $\begin{array}{c}\text { TA } \\
\left(\mathrm{g} 100 \cdot \mathrm{mL}^{-1}\right)\end{array}$ & SS/TA \\
\hline Thompson Seedless & $9.28 c$ & $30 d$ & $250.84 b$ & $11.05 a$ & $18.18 c$ & $0.44 d$ & $43.2 a$ \\
\hline Crimson Seedless & $11.12 \mathrm{c}$ & $31 d$ & $278.97 \mathrm{~b}$ & $11.82 a$ & $17.10 c$ & $0.72 a$ & $27.8 \mathrm{c}$ \\
\hline BRS Clara & $16.14 b$ & $51 \mathrm{c}$ & $233.85 b$ & $11.36 a$ & $19.48 b$ & $0.45 d$ & $48.0 \mathrm{a}$ \\
\hline BRS Linda & $26.44 a$ & $65 b$ & $238.88 \mathrm{~b}$ & $9.48 \mathrm{~b}$ & $15.14 \mathrm{e}$ & $0.34 \mathrm{e}$ & $46.4 a$ \\
\hline Arizul & $15.36 \mathrm{~b}$ & $47 c$ & $235.47 b$ & $10.29 a$ & $17.37 \mathrm{c}$ & $0.55 c$ & $33.9 c$ \\
\hline A 1105 & $24.32 a$ & $67 \mathrm{~b}$ & $273.90 \mathrm{~b}$ & $11.07 a$ & $17.24 c$ & $0.64 b$ & $31.4 c$ \\
\hline Marroo & $26.49 a$ & $82 a$ & $261.14 b$ & $12.12 a$ & $14.82 \mathrm{e}$ & $0.38 d$ & $40.5 b$ \\
\hline A Dona & $20.23 a$ & $80 a$ & $199.84 b$ & $11.09 a$ & $21.63 a$ & $0.58 c$ & $39.6 \mathrm{~b}$ \\
\hline CNPUV 8 & $14.96 \mathrm{~b}$ & $47 c$ & $254.79 b$ & $9.42 b$ & $15.97 d$ & $0.43 d$ & $43.5 a$ \\
\hline CNPUV 23 & $24.96 a$ & $90 a$ & $327.10 a$ & $10.54 a$ & $13.35 f$ & $0.27 f$ & $52.9 a$ \\
\hline CNPUV 24 & $10.10 c$ & $46 c$ & $176.17 \mathrm{c}$ & $8.74 b$ & $17.72 c$ & $0.52 c$ & $38.4 \mathrm{~b}$ \\
\hline CNPUV 25 & $8.48 c$ & $53 c$ & $147.21 \mathrm{c}$ & $6.86 c$ & $17.75 c$ & $0.53 c$ & $36.6 \mathrm{~b}$ \\
\hline CNPUV 44 & $15.00 \mathrm{~b}$ & $61 b$ & $178.01 \mathrm{c}$ & $9.48 b$ & $16.62 d$ & $0.54 c$ & $33.1 \mathrm{c}$ \\
\hline CNPUV 36 & $12.92 \mathrm{~b}$ & $56 c$ & $198.53 c$ & $8.26 \mathrm{~b}$ & $19.34 b$ & $0.46 \mathrm{~d}$ & $48.8 \mathrm{a}$ \\
\hline Mean & 16.84 & 58 & 232.48 & 10.11 & 17.26 & 0.49 & 40.3 \\
\hline CV (\%) & 21.49 & 15.76 & 12.66 & 9.94 & 5.02 & 8.56 & 12.04 \\
\hline
\end{tabular}

Means from five production cycles (2014 to 2018). Means followed by the same letter in the columns are not different by the Scott-Knott test ( $p<0.05$ ).

Table 3. Means and standard deviation for bunch length, berry weight, berry length, and berry diameter of 14 table grape genotypes over five crop seasons (2014-2018). Petrolina, PE, Brazil.

\begin{tabular}{ccccc}
\hline Genotypes & $\begin{array}{c}\text { Bunch } \\
\text { length }(\mathbf{c m})\end{array}$ & $\begin{array}{c}\text { Berry } \\
\text { weight (g) }\end{array}$ & $\begin{array}{c}\text { Berry } \\
\text { length (mm) }\end{array}$ & $\begin{array}{c}\text { Berry } \\
\text { diameter (mm) }\end{array}$ \\
\hline Thompson Seedless & $16.14 \pm 0.38$ & $2.34 \pm 0.34$ & $17.99 \pm 0.91$ & $15.04 \pm 0.68$ \\
\hline Crimson Seedless & $18.27 \pm 1.90$ & $3.17 \pm 0.29$ & $21.39 \pm 0.62$ & $16.22 \pm 0.60$ \\
\hline BRS Clara & $16.51 \pm 0.26$ & $2.58 \pm 0.14$ & $20.44 \pm 0.55$ & $15.38 \pm 0.34$ \\
\hline BRS Linda & $16.51 \pm 0.96$ & $4.55 \pm 0.58$ & $23.78 \pm 1.09$ & $18.64 \pm 1.28$ \\
\hline Arizul & $18.03 \pm 0.95$ & $1.81 \pm 0.27$ & $24.51 \pm 0.58$ & $14.60 \pm 0.65$ \\
\hline The 1105 & $16.78 \pm 0.82$ & $4.96 \pm 0.54$ & $20.43 \pm 0.31$ & $18.96 \pm 0.57$ \\
\hline Marroo & $16.60 \pm 0.71$ & $3.73 \pm 0.13$ & $17.90 \pm 0.35$ & $18.05 \pm 0.39$ \\
\hline A Dona & $18.73 \pm 0.95$ & $2.23 \pm 0.09$ & $22.81 \pm 0.14$ & $15.33 \pm 0.04$ \\
\hline CNPUV 8 & $16.49 \pm 0.19$ & $3.39 \pm 0.09$ & $23.05 \pm 0.43$ & $17.56 \pm 0.35$ \\
\hline CNPUV 23 & $18.93 \pm 1.27$ & $5.55 \pm 0.35$ & $22.31 \pm 0.21$ & $20.44 \pm 0.53$ \\
\hline CNPUV 24 & $16.18 \pm 0.49$ & $3.17 \pm 0.13$ & $22.29 \pm 0.68$ & $16.13 \pm 0.11$ \\
\hline CNPUV 25 & $12.05 \pm 0.38$ & $3.04 \pm 0.25$ & $22.13 \pm 0.48$ & $16.72 \pm 0.37$ \\
\hline CNPUV 44 & $17.06 \pm 1.11$ & $2.97 \pm 0.20$ & $21.23 \pm 0.45$ & $16.15 \pm 0.42$ \\
\hline CNPUV 36 & $14.82 \pm 0.63$ & $3.08 \pm 0.14$ & $21.21 \pm 2.30$ & $15.94 \pm 0.27$ \\
\hline Mean & $16.65 \pm 1.86$ & $3.33 \pm 1.06$ & $16.79 \pm 1.72$ \\
\hline
\end{tabular}

Means from five production cycles (2014 to 2018). 
use of biostimulants and growth regulators that promote bunch elongations and increase berry size, resulting in higher bunch weight (Leão 2018). The bunch weight of CNPUV 23 was higher than those of the other genotypes, presenting higher bunch and berry weight and size (Table 3). Bunches with length of approximately $18 \mathrm{~cm}$ were found for the cultivars Crimson Seedless, Arizul, A Dona, and for the genotype CNPUV 23, which also had higher width than the bunches of BRS Linda and other genotypes of the Embrapa Grape and Wine breeding program.

Large berry size is a desirable characteristic because it contributes to the grape appearance. In China, this is one of the main characteristics considered by growers for the adoption of new table grape cultivars (Wang et al. 2017); thus, it is included among the most important objectives of breeders for the development of cultivars (Töpfer et al. 2011). The cultivar BRS Linda presented large berry size, and had means of berry length and diameter similar to those described at the launching of the cultivar (Camargo et al. 2003a). The means found in the present study for berry weight, length, and diameter of 'Marroo Seedless' were higher than those found in Thailand (Kittiwatsopon and Karintanyakit 2014), and similar to previous results obtained in the São Francisco Valley (Leão 2002).

The genotypes presented significant differences for soluble solid contents (SS), titratable acidity (TA), and SS to TA ratio (SS/TA) (Table 2), which are traditionally considered for characterization of grape maturation and are used worldwide as primary indexes for classification of exported fruits. Minimum SS and SS/TA are specified for each table grape cultivar (Daniels et al. 2019). The genetic material is a key factor, which determines the preharvest conditions and physicochemical, organoleptic, and functional qualities of fresh fruits and vegetables, often surpassing the impact of agronomical and environmental factors (Kyriacou and Rouphael 2018).

The mean for SS was $17.26^{\circ}$ Brix (Table 2); only the genotype CNPUV 23 presented lower SS than the minimum SS described in Brazilian norms for marketing of table grapes (Brazil 2002). The cultivars A Dona, BRS Clara, and the genotype CNPUV 36 had the highest SS: 21.6, 19.4, and $19.3^{\circ}$ Brix, respectively. The SS found for the cultivar BRS Clara was similar to those described previously for this seedless table grape cultivar (Leão 2018; Camargo et al. 2003b).

The mean for TA was $0.49 \mathrm{~g} \cdot 100 \mathrm{~mL}^{-1}$, denoting that most genotypes evaluated presented intermediate TA. 'Crimson Seedless' presented grapes with higher acidity $\left(0.72 \mathrm{~g} \cdot 100 \mathrm{~mL}^{-1}\right)$ than the other genotypes. The lowest TA means were found for the genotypes CNPUV 23, Marroo Seedless, and BRS Linda, resulting in very high SS/TA, and grapes with inexpressive flavor. According to South Africa's standards and requirements related to the control of export of table grapes, the acceptable SS/TA is 22 for 'Prime Seedless', 24 for 'Regal Seedless', and 21 for 'Thompson Seedless', which are lower than those found in the present work.

The multivariate analysis by principal components showed that most variance (81.9\%) was explained by the three first components, which were used to plot the genotypes into the bidimensional space (Fig. 1). Positive and significant correlations were found between yield and number of bunches $(r=0.81)$, berry diameter $(r=0.70)$, and berry weight $(r=0.65)$; and SS presented negative correlation with all production variables evaluated, presenting positive correlation only with titratable acidity $(r=0.52)$. The principal component 1 explained $45.26 \%$ of the total variance, and the variables with higher weight on this component were berry diameter, weight, and yield. The principal component 2 explained $22.17 \%$ of the total variance, represented mainly by bunch length and width. The principal component 3 explained $14.52 \%$ of the variance, represented mainly by SS/TA, TA, and berry length.

The graphical representation of scores of the three first principal components showed coherence with the groups formed by the Scott-Knott test, placing the genotypes CNPUV 23, Marroo Seedless, A1105, and BRS Linda at the right side of the $X$-axis because of their higher yield and other variables correlated with yield; the genotypes that presented higher SS and TA were placed at the left side of the $X$-axis (Fig. 1).

The results obtained in the present work allowed the evaluation of the yield performance and physicochemical characteristics of the seedless table grape cultivars and genotypes evaluated in the tropical semiarid conditions of the São Francisco Valley, Brazil, when compared to traditional cultivars Thompson Seedless and Crimson Seedless; these results also allow the recommendation of cultivars with commercial potential or, despite their limiting characteristics, to be used as parents in a local breeding program aiming develop seedless table grapes adapted to the environmental conditions of the Brazilian Semiarid region. 


\section{CONCLUSION}

The seedless table grape genotypes Marroo Seedless, BRS Linda, CNPUV 23, A1105, and A Dona presented higher yields than the commercial cultivars Thompson Seedless and Crimson seedless.

The genotype CNPUV 23 presented the highest yield, bunch size, and berry size, but presented low soluble solid and titratable acidity contents, resulting in an unbalanced SS to TA ratio and grapes with inexpressive flavor.

Principal component analysis showed that the first three principal components explained $81.9 \%$ of the data variance, identifying a group of seedless grape cultivars that can be used for commercial crops or as parents for controlled crossings in a local table grape breeding program.

\section{AUTHOR'S CONTRIBUTION}

Conceptualization, Leão, P. C. S.; Methodology, Leão, P. C. S.; Investigation, Leão, P. C. S., Nascimento, J. H. B., Moraes, D. S. and Souza, E. R.; Writing - Original Draft, Leão, P. C. S.; Writing - Review and Editing, Leão, P. C. S.; Funding Acquisition, Leão, P. C. S.

\section{REFERENCES}

[Agrianual] Anuário da Agricultura Brasileira. (2019). Agrianual 2019 traz estatísticas de 55 culturas (p. 431-440). São Paulo: FNP Consultoria. [Brazil] Ministério da Agricultura, Pecuária e Abastecimento. (2002). Instrução Normativa No 1, de 01 de fevereiro de 2002. ANEXO II - Regulamento técnico de identidade e de qualidade para a classificação da uva fina de mesa. Brasília: Diário Oficial da República Federativa do Brasil. [Accessed Jan. 25 2020. Available at: https://www.ibravin.org.br/admin/arquivos/leis/1456252027.pdf

[IBGE] Instituto Brasileiro de Geografia e Estatística. (2018). Produção agrícola municipal - PAM. [Accessed Dec. 5 2019. Available at: https://www.ibge.gov.br/estatisticas-novoportal/economicas/agricultura-e-pecuaria/9117-producao-agricolamunicipal-culturastemporarias-e-permanentes.html? =\&t=resultados

Allen, R. G., Pereira, L. S., Raes, D. and Smith, M. (1998). Crop evapotranspiration: Guidelines for computing crop water requirements FAO Irrigation and drainage paper 56. Rome: FAO. [Accessed Aug. 28 2019]. Available at: http://www.fao.org/3/x0490e/x0490e00.htm

Alvares, C. A., Stape, J. L., Sentelhas, P. C., Gonçalves, J. L. M. and Sparovek, G. (2014). Köppen’s climate classification map for Brazil. Meteorologische Zeitschrift, 22, 711-728. https://doi.org/10.1127/0941-2948/2013/0507

Association of Official Agricultural Chemist (2010). Official methods of analysis of the Association of the Agricultural Chemists. Gaithersburg: AOAC. Atak, A. and Kahraman, A. K. (2014). New table grapes in turkey. BIO Web of Conferences, 3, 01002. https://doi.org/10.1051/ bioconf/20140301002

Burger, P., Vermeulen, A., Halleen, F., Koopman, T., van Heerden, C. J. and Prins, R. (2014). Table grape breeding at the ARC InfruitecNietvoorbij, South Africa: Its impact on the SA industry and latest developments. Acta Horticulturae, 1046, 245-249. https://doi.org/10.17660/ ActaHortic.2014.1046.31

Camargo, U. A., Nachtigal, J. C., Maia, J. D. G., Oliveira, P. R. D. and Protas, J. F. S. (2003a). BRS Linda: nova cultivar de uva branca de mesa sem semente [Comunicado Técnico 48]. Bento Gonçalves: Embrapa Uva e Vinho. [Accessed Dec. 8 2019]. Available at: http:// ainfo.cnptia.embrapa.br/digital/bitstream/CNPUV/5277/1/cot048.pdf

Camargo, U. A., Nachtigal, J. C., Maia, J. D. G., Oliveira, P. R. D. and Protas, J. F. S. (2003b). BRS Clara: nova cultivar de uva branca de mesa sem semente [Comunicado Técnico 46]. Bento Gonçalves: Embrapa Uva e Vinho. [Dec.08 2019. Available at: http://ainfo.cnptia. embrapa.br/digital/bitstream/CNPUV/5274/1/cot046.pdf 
Clark, J. R. and Moore, J. N. (2015). 'Faith', ‘Gratitude', 'Hope’ and ‘Joy’ seedless table grapes from Arkansas, USA. Acta Horticulturae, 1082, 87-93. https://doi.org/10.17660/ActaHortic.2015.1082.11

Cunha, T. J. F., Silva, F. H. B. B., Silva, M. S. L., Petrere, V. G., Sá, I. B., Oliveira Neto, M. B. and Cavalcanti, A. C. (2008). Solos do Submédio do Vale do São Francisco: potencialidades e limitações para uso agrícola [Documentos 211]. Petrolina: Embrapa Semiárido. [Accessed Jan. 20 2020]. Available at: http://www.cpatsa.embrapa.br/public_eletronica/downloads/SDC211.pdf

Daniels, A. J., Poblete-Echeverría, C., Opara, U. L. and Nieuwoudt, H. H. (2019). Measuring internal maturity parameters contactless on intact table grape bunches using NIR spectroscopy. Frontiers in Plant Science, 10, 1517. https://doi.org/10.3389/fpls.2019.01517

Kittiwatsopon, K. and Karintanyakit, P. (2014). Effect of CPPU and GA ${ }_{3}$ on growth and quality of 'Marroo seedless' grape. Acta Horticulturae, 1059, 189-194. https://doi.org/10.17660/ActaHortic.2014.1059.24

Kyriacou, M. C. and Rouphael, Y. (2018). Towards a new definition of quality for fresh fruits and vegetables. Scientia Horticulturae, 234, 463-469.

Leão, P. C. S. (2002). Comportamento de cultivares de uva sem sementes no submédio São Francisco. Revista Brasileira de Fruticultura, 24, 734-737. https://doi.org/10.1590/S0100-29452002000300043

Leão, P. C. S., Souza, E. M. C., Nascimento, J. H. B. and Rego, J. I. S. (2017). Bud fertility of new table grape cultivars and breeding selections in the São Francisco Valley. Revista Brasileira de Fruticultura, 39, e-042. https://doi.org/10.1590/0100-29452017042

Leão, P. C. S. (2018). Poda e manejo da copa. In Uva: do plantio à colheita (p. 104-123). Viçosa: Editora UFV.

Maia, J. D. G., Ritschel, P. S., Camargo, U. A., Souza, R. T., Fajardo, T. V. M., Naves, R. L. and Girardi, C. L. (2012). 'BRS Vitória’ Nova cultivar de uva de mesa sem sementes com sabor especial e tolerante ao míldio [Comunicado Técnico 126]. Bento Gonçalves: Embrapa Uva e Vinho. [Accessed Jan. 20 2020]. Available at: http://ainfo.cnptia.embrapa.br/digital/bitstream/item/71804/1/cot126.pdf

Maia, J. D. G., Ritschel, P. S., Camargo, U. A., Souza, R. T., Fajardo, T. V. M. and Girardi, C. L. (2013). BRS Núbia: nova cultivar de uva de mesa com sementes e coloração preta uniforme [Comunicado Técnico 139]. Bento Gonçalves: Embrapa Uva e Vinho. [Accessed Jan. 20 2020]. Available at: http://ainfo.cnptia.embrapa.br/digital/bitstream/item/92703/1/cot-139.pdf

Ritschel, P. S., Maia, J. D. G., Camargo, U. A., Souza, R. T., Fajardo, T. V. M., Naves, R. L. and Girardi, C. L. (2013). BRS Isis: nova cultivar de uva de mesa vermelha, sem sementes e tolerante ao míldio [Comunicado Técnico 143]. Bento Gonçalves: Embrapa Uva e Vinho. [Accessed Jan. 20 2020. Available at: http://ainfo.cnptia.embrapa.br/digital/bitstream/item/123194/1/cot143.pdf

Töpfer, R., Hausmann, L., Harst, M., Maul, E., Zyprian, E. and Eibach, R. (2011). New horizons for grapevine breeding. Fruit, Vegetable and Cereal Science and Biotechnology, 5, Special Issue 1, 79-100.

Wang, Z., Zhou, J., Xu, X., Perl, A., Chen, S. and Ma, H. (2017). Adoption of table grape cultivars: An attribute preference study on Chinese grape growers. Scientia Horticulturae, 216, 66-75. https://doi.org/10.1016/j.scienta.2017.01.001

Xu, H. Y., Zhang, G. J., Yan, A. L. and Sun, L. (2015). Table Grape Breeding at the Beijing Institute of Forestry and Pomology. Acta Horticulturae, 1082, 43-46. https://doi.org/10.17660/ActaHortic.2015.1082.3 